\title{
Water Level Controls on Sap Flux of Canopy Species in Black Ash Wetlands
}

\author{
Joseph Shannon ${ }^{1, *}(\mathbb{D})$, Matthew Van Grinsven ${ }^{1,2} \mathbb{1}^{\mathbb{D}}$, Joshua Davis ${ }^{1}$ (i), Nicholas Bolton ${ }^{1,3}$, \\ Nam Jin Noh ${ }^{1,4}$ (iD), Thomas Pypker ${ }^{5}$ and Randall Kolka ${ }^{6}$ \\ 1 School of Forest Resources \& Environmental Science, Michigan Technological University, \\ Houghton, MI 49931, USA; mvangrin@nmu.edu (M.V.G.); joshuad@mtu.edu (J.D.); \\ nwbolton@mtu.edu (N.B.); n.noh@westernsydney.edu.au (N.J.N.) \\ 2 Department of Earth, Environment, \& Geosciences, Northern Michigan University, \\ Marquette, MI 49985, USA \\ 3 D.B. Warnell School of Forestry \& Natural Resources, University of Georgia, Athens, GA 30602, USA \\ 4 Hawkesbury Institute for the Environment, Western Sydney University, Richmond, NSW 2753, Australia \\ 5 Department of Natural Resource Science, Thompson Rivers University, Kamloops, BC V2C 0C8, Canada; \\ tpypker@tru.ca \\ 6 Northern Research Station, USDA Forest Service, Grand Rapids, MN 55744, USA; rkolka@fs.fed.us \\ * Correspondence: jpshanno@mtu.edu; Tel.: +1-906-487-1831
}

Received: 21 February 2018; Accepted: 14 March 2018; Published: 16 March 2018

\begin{abstract}
Black ash (Fraxinus nigra Marsh.) exhibits canopy dominance in regularly inundated wetlands, suggesting advantageous adaptation. Black ash mortality due to emerald ash borer (Agrilus planipennis Fairmaire) will alter canopy composition and site hydrology. Retention of these forested wetlands requires understanding black ash's ecohydrologic role. Our study examined the response of sap flux to water level and atmospheric drivers in three codominant species: black ash, red maple (Acer rubrum L.), and yellow birch (Betula alleghaniensis Britt.), in depressional wetlands in western Michigan, USA. The influence of water level on sap flux rates and response to vapor pressure deficit $(V P D)$ was tested among species. Black ash had significantly greater sap flux than non-black ash at all water levels (80-160\% higher). Black ash showed a significant increase (45\%) in sap flux rates as water levels decreased. Black ash and red maple showed significant increases in response to VPD as water levels decreased (112\% and 56\%, respectively). Exploration of alternative canopy species has focused on the survival and growth of seedlings, but our findings show important differences in water use and response to hydrologic drivers among species. Understanding how a replacement species will respond to the expected altered hydrologic regimes of black ash wetlands following EAB infestation will improve species selection.
\end{abstract}

Keywords: transpiration; Fraxinus nigra; ecohydrology; emerald ash borer; mitigation; water table; flooding; inundation

\section{Introduction}

Emerald ash borer (EAB, Agrilus planipennis Fairmaire), an exotic insect native to Asia and first detected in southeastern Michigan, USA, in 2002, has been spreading outward after introduction [1,2]. EAB has caused a regional trend of declining native ash (Fraxinus spp.) populations in the Great Lakes States observable since 2004 [3]. The loss of native ash throughout their ranges in North America has been shown to have important economic [4], cultural [5], and ecological [6] impacts. The northwestern periphery of the expanding infestation includes areas where black ash (Fraxinus nigra Marsh.) plays an important role on the landscape [7] (Figure 1). Black ash grows on wet sites with persistently high water tables or seasonal inundation [8]. These wet sites are classified as northern hardwood swamps 
in Michigan [9] and Wisconsin [10], and northern wet ash swamps and northern very wet ash swamps in Minnesota [11]. Black ash is the dominant canopy species in all of these classifications, which makes them of particular concern regarding EAB infestation. Current research is studying the anticipated effects of EAB infestation in these communities on vegetation composition [12,13], hydrology [14,15], suitable replacement species and planting strategies [16-18], and carbon and nitrogen cycling [18-20].

Hydrology is an important control on wetland ecotype and function [21], so that alteration to the hydrology of a wetland can lead to a change in wetland ecotype, or conversion to open water or mesic forest. Evapotranspiration is a major driver of hydrologic regimes; in the Great Lakes region, evapotranspiration accounts for $50-70 \%$ of annual precipitation [22]. In depressional wetlands of western Michigan, black ash can account for up to 70\% of growing season canopy transpiration [15]. Therefore, disturbance of the forest canopy is likely to affect the hydrology of the wetland [23-25].

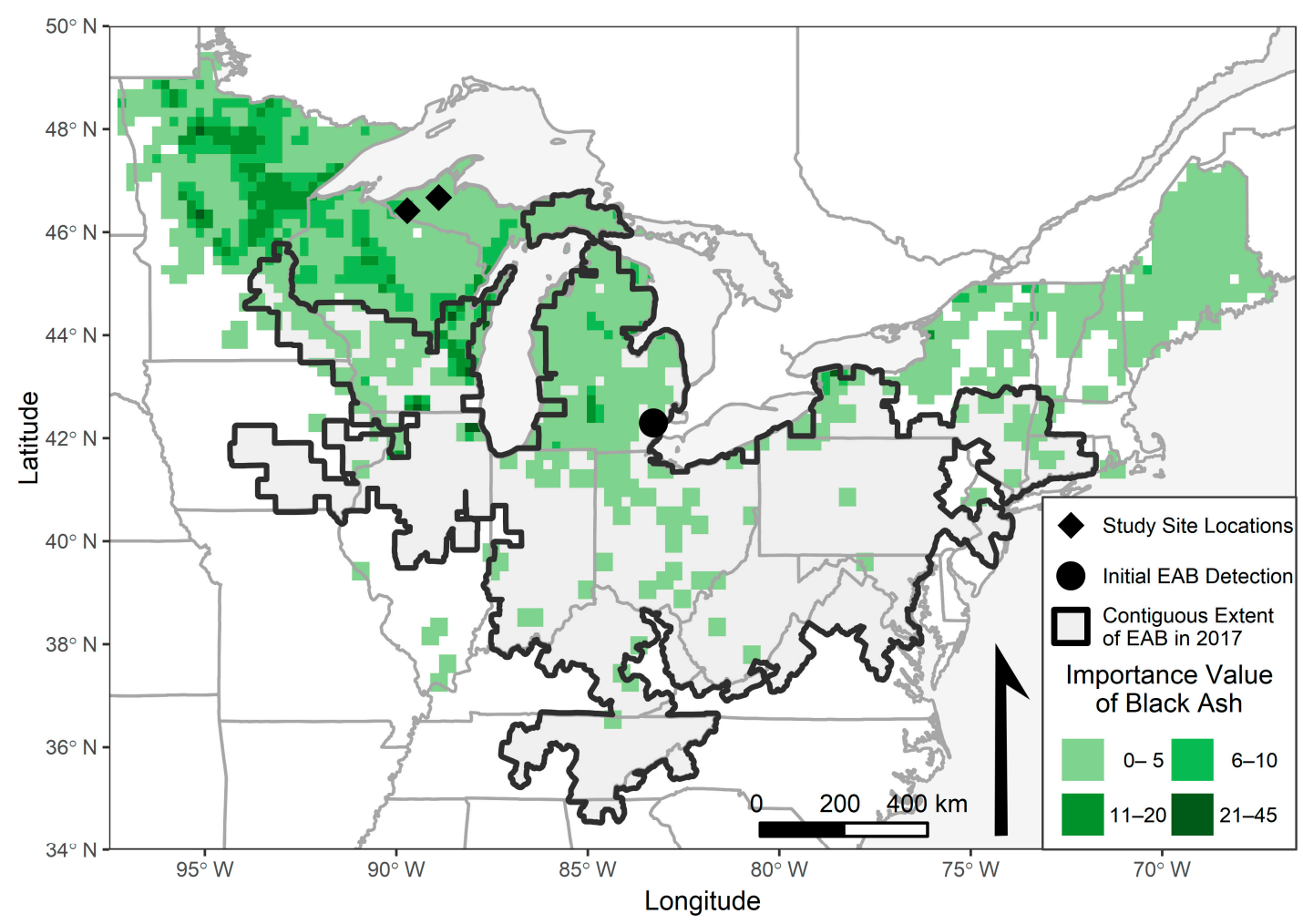

Figure 1. Extent of contiguous counties with detected emerald ash borer in 2017 [26] and the current Importance Value of black ash in the United States derived from US Forest Service Forest Inventory and Analysis data [7]. Initial Emerald ash borer (EAB) detection in Wayne County, Michigan, USA (2002) and study site locations also shown.

Recent research in black ash wetlands has shown a significant hydrologic response to the loss of black ash in the canopy following treatments aimed at simulating infestation of EAB or potential preemptive management approaches [14,15]. In both studies, water table elevation increased and/or rates of water table drawdown through the growing season were reduced following treatment when compared to unharvested control sites. These anticipated changes to the hydrology of EAB-infested black ash wetlands may result in more frequent and longer-lasting soil saturation and inundation. Slesak et al. [14] and Van Grinsven et al. [15] both present two years of post-treatment data. Longer records of the hydrologic response of these wetlands to the loss of black ash as the dominant canopy species is not available due to the relatively recent infestation of EAB in these sites.

The importance of the forest canopy in wetland function has led to studies focused on suitable replacement species for black ash with respect to the survival and growth of seedlings [16-18], but to 
our knowledge, none have studied the suitability of replacement species regarding the ecohydrologic function of mature individuals. The dominance of black ash as a canopy species in these wetland communities suggests adaptation to inundation and saturated soils [27]. Hypertrophied lenticels and adventitious roots have been observed on black ash (Personal Observation, [28]). Tardiff et al. [28] found that black ash regeneration could favor sexual or asexual reproduction dependent upon water levels. Green ash (Fraxinus pennsylvanica Marshall) has been shown to regulate stomatal openings, developing adventitious roots, hypertrophied lenticels, and aerenchyma tissues in response to inundation [29,30]. Other species, including red maple (Acer rubrum L.) [31], sweetgum (Liquidambar styraciflua L.), [32], white spruce (Picea glauca, (Moench) Voss) and tamarack (Larix laricina (Du Roi) K. Koch) [33], and American elm (Ulmus americana L.) [34], have shown some of these responses in seedlings in controlled settings. These adaptations as observed in seedlings may not be sufficient to sustain mature populations, as differences persist among wet-site adapted species with respect to long-term inundation and inundation during sensitive periods [35]. Mature individuals of flood-adapted species frequently continue transpiration during periods of inundation $[23,32,36]$, but no study has examined species-level variation in transpiration under inundated conditions.

We aim to inform long-term predictions about the effects of EAB on the hydrology of black ash wetlands by examining the effect of the water table on sap flux rates and the effect of the water table on the sap flux response to atmospheric drivers. We hypothesize higher rates of sap flux in black ash than in codominants at high water levels, with the difference diminishing as water levels decrease. We also hypothesize a suppressed sap flux response to vapor pressure deficit in codominants relative to black ash as water levels increase.

\section{Materials and Methods}

\subsection{Study Area}

Six study sites were located in the Ottawa National Forest in the western Upper Peninsula of Michigan, where mean annual precipitation is $1010 \mathrm{~mm}$ and mean annual temperature is $4.2^{\circ} \mathrm{C}$ [37]. Sites were northern hardwood swamps as described by Kost et al. [9], with the most abundant canopy species being black ash $19 \mathrm{~m}^{2} \mathrm{ha}^{-1}$, yellow birch (Betula alleghaniensis Britt.) $3.5 \mathrm{~m}^{2} \mathrm{ha}^{-1}$, and red maple $2.5 \mathrm{~m}^{2} \mathrm{ha}^{-1}$ [12]. The wetlands were located in landscape depressions and had an average size of 0.4 ha (range: $0.2-0.8 \mathrm{ha}$ ). Soils were histosols over poorly-sorted till or clay with an average depth to a confining layer of $118.8 \mathrm{~cm}$. In three of the study sites, black ash stems greater than $2.54 \mathrm{~cm}$ diameter at breast height (DBH, $1.37 \mathrm{~m}$ ) were girdled in the winter of 2013 to mimic an EAB infestation. Girdled black ash were not included in this study and girdling impacts on red maple and yellow birch were not addressed by this study.

\subsection{Field Measures}

Sap flux data were collected during the 2012, 2013, and 2014 growing seasons using $2 \mathrm{~cm}$ thermal heat dissipation probes [38,39] centered at DBH. To avoid potential impacts of probe age [40], new probes were installed during each growing season at a $60^{\circ}$ offset around the circumference of the sampled stem. Probes were insulated using foam insulation and reflective wrapping to avoid the influence of external temperature gradients [41]. Voltage differentials were logged at 15-min intervals at each study site using a CR1000 datalogger and two AM 16/32B multiplexers (Campbell Scientific, Logan, UT, USA). Sample trees were selected across the range of diameter sizes observed in vegetation surveys (Table 1) [12]. Measurements across all study sites were collected on six black ash stems (at four sites), five red maple stems (at three sites), and six yellow birch stems (at four sites). Sapwood area for black ash was predicted from diameter at breast height using a linear regression fit with visually-determined sapwood area from stem cross-sections of felled ash trees. Existing empirical equations were used to calculate sapwood area for yellow birch [42] and red maple [43]. 
A $5 \mathrm{~cm}$ inner-diameter monitoring well was installed at each study site close to the wetland outlet, and a pressure transducer (Levellogger Junior M5, Solinst Canada Ltd., Georgetown, ON, Canada) recorded water levels at 15-min intervals [15]. The elevation of the root collar of each sampled stem relative to the corresponding study site monitoring well was determined by an optical survey (Leica Viva TS11 Manual Total Station, Leica Geosystems, Inc., Norcross, GA, USA).

Table 1. Number of trees instrumented for sap flux measurements along with mean diameter and diameter ranges of instrumented trees.

\begin{tabular}{cccc}
\hline Species & Number of Instrumented Trees & Mean Diameter $\mathbf{( c m )}$ & Range of Diameters (cm) \\
\hline Black Ash & 6 & 25.58 & $15.00,40.00$ \\
Red Maple & 5 & 23.12 & $18.00,34.10$ \\
Yellow Birch & 6 & 24.62 & $13.00,39.10$ \\
\hline
\end{tabular}

Daily [44] and hourly [45] meteorological data were retrieved from remote automated weather stations located in Wakefield, MI (WKFM4, UTM 16N 282871, 5146850) and Pelkie, MI (PIEM4, UTM 16 N 373047, 5182028), which are within $26.1 \mathrm{~km}$ of our study sites. Mean daily daylight-normalized vapor pressure deficit $\left(D_{z}\right)$ was calculated as the mean daily vapor pressure deficit where solar radiation was greater than or equal to $50 \mathrm{~W} \mathrm{~m}^{-2}[46,47]$.

\subsection{Data Analysis}

Sap flux densities $\left(Q_{s} ; \mathrm{m}^{3} \mathrm{~m}^{-2} \mathrm{~s}^{-1}\right)$ were calculated for black ash using an empirical equation derived for European ash (Fraxinus excelsior L.) [48], which better represents the ring-porous structure of black ash:

$$
Q_{s}\left(\mathrm{~m}^{3} \mathrm{~m}^{-2} \mathrm{~s}^{-1}\right)=2.023\left(\frac{\Delta V_{m}-\Delta V}{\Delta V}\right)^{2}+0.428\left(\frac{\Delta V_{m}-\Delta V}{\Delta V}\right),
$$

where $Q_{s}$ is the sap flux density in $\mathrm{m}^{3} \mathrm{~m}^{-2}$ day ${ }^{-1}, \Delta V$ is the voltage differential across the probes, and $\Delta V_{m}$ is the maximum $\Delta V$ for that day.

For red maple and yellow birch, voltage differentials were converted to sap flux densities using the empirical equation from Lu ([49]), modified from Granier [38,39]:

$$
Q_{s}\left(\mathrm{~m}^{3} \mathrm{~m}^{-2} \mathrm{~s}^{-1}\right)=118.9 \times 10^{-6} \times\left(\frac{\Delta V_{m}-\Delta V}{\Delta V}\right)^{1.231}
$$

where all definitions are as above.

For all species, when sapwood depth was less than the length of the probe, corrected voltage differentials were calculated according to Clearwater et al. [50]. Instantaneous sap flux density was assumed to be constant over the logging interval and daily sap flux densities $\left(J_{s} ; \mathrm{m}^{3} \mathrm{~m}^{-2}\right.$ day $\left.^{-1}\right)$ were calculated as the sum of $Q_{s}$ for each sensor. To remove the influence of phenological differences among species on measured sap flux [51], only data from June, July, and August were included in the analysis.

Daily mean water level for each well was calculated from logged 15-min data. Water level relative to the root collar of each sample tree was calculated as the monitoring well water level minus the relative elevation difference between the soil surface at the monitoring well and the root collar. For the analysis of species-level differences at high, mean, and low water levels, water levels were binned with breakpoints defined as $\mu \pm 0.5 \sigma$. Breakpoints were calculated separately for each species to account for differences in relative elevation.

Response of daily sap flux to daylight-normalized vapor pressure deficit and binned mean daily water level was fit using a mixed-effects model with the lme4 package [52] in R [53,54]. Species, 
water table bin, and square-root transformed $D_{z}$ were used as fixed effects, and each probe as the random effect:

$$
J_{s}\left(\mathrm{~g} \mathrm{~cm}^{-2} \mathrm{day}^{-1}\right)=\text { Species } \times W L_{\mathrm{bin}} \times \sqrt{D_{z}(k P a)}+\left(W L_{\mathrm{bin}} \times \sqrt{D_{z}(k P a)} \mid \text { probe }\right),
$$

where $J_{s}$ is the cumulative daily sap flux, $W L_{\text {bin }}$ is the binned water level, and $D_{z}$ is the daylight-normalized vapor pressure deficit.

Differences in sap-flux response to $D_{z}$ and water level were compared among and within species using the emmeans package [55]. For all comparisons, $p$-values were adjusted using the Tukey post-hoc method.

\section{Results}

\subsection{Stem Elevations and Water Levels}

In all cases, the stem root collar was at a higher elevation than the soil surface at the monitoring well. Relative root collar elevations were significantly lower in black ash (mean: $33.3 \mathrm{~cm}$, standard error (se): $1.8 \mathrm{~cm}$ ) compared with red maple (mean: $42.8 \mathrm{~cm}$, se: $3.0 \mathrm{~cm}$ ) and yellow birch (mean: $45.3 \mathrm{~cm}$, se: $2.4 \mathrm{~cm}$ ). Water levels relative to the surveyed root collar elevation ranged from -82.6 to $1.9 \mathrm{~cm}$ in black ash, -122.1 to $-21.2 \mathrm{~cm}$ in red maple, and -127.0 to $-18.5 \mathrm{~cm}$ in yellow birch (Table 2).

Table 2. Range of observed water levels $(\mathrm{cm})$ for each species and water level bin. Water levels are reported as distance above $(+)$ or below $(-)$ the tree root collar.

\begin{tabular}{cccccc}
\hline Species & $\begin{array}{c}\text { Minimum } \\
\text { Observed }(\mathbf{c m})\end{array}$ & $\begin{array}{c}\text { Low/Mean } \\
\text { Threshold }(\mathbf{c m})\end{array}$ & $\begin{array}{c}\text { Mean } \\
\text { Observed }(\mathbf{c m})\end{array}$ & $\begin{array}{c}\text { Mean/High } \\
\text { Threshold }(\mathbf{c m})\end{array}$ & $\begin{array}{c}\text { Maximum } \\
\text { Observed }(\mathbf{c m})\end{array}$ \\
\hline Black Ash & -82.6 & -46.5 & -37.3 & -28.0 & 1.6 \\
Red Maple & -122.1 & -61.8 & -51.7 & -41.7 & -21.2 \\
Yellow Birch & -127.0 & -62.0 & -51.9 & -41.8 & -18.5 \\
\hline
\end{tabular}

\subsection{Mean Sap Flux Rates, Individual Drivers, and Interaction of Drivers}

The complete model (Equation 3) had a marginal $R^{2}$ of 0.29 and a conditional $R^{2}$ of 0.80 [56], effect size and exact $p$-value for all pairwise comparisons can be found in Table S1. Daily sap flux rates were significantly greater in black ash than in non-black ash species at all water levels (Table 3). Within black ash, daily sap flux dropped significantly between each increasing water level bin (Table 3). There were no significant differences in daily sap flux rates among water level bins for red maple or yellow birch (Table 3). When $D_{z}$ and water level are considered as separate drivers, all species showed a positive relationship between square-root transformed $D_{z}$ and daily sap flux (Figure S1). Sap flux in black ash showed a negative response to increasing water levels, red maple no response to water level changes, and yellow birch a slight positive response to water level as an individual driver (Figure S1).

Table 3. Estimated marginal mean sap flux $\left(\mathrm{m}^{3} \mathrm{~m}^{-2} \mathrm{day}^{-1}\right)$ and standard error by species and water level bin.

\begin{tabular}{cccc}
\hline Species & Low Water Level & Mean Water Level & High Water Level \\
\hline Black Ash & $4.00 \pm 0.30^{a ; 1}$ & $3.13 \pm 0.29^{a ; 2}$ & $2.76 \pm 0.31^{a ; 3}$ \\
Red Maple & $1.63 \pm 0.21^{b ; 1}$ & $1.60 \pm 0.21^{b ; 1}$ & $1.49 \pm 0.22^{b ; 1}$ \\
Yellow Birch & $1.52 \pm 0.20^{b ; 1}$ & $1.56 \pm 0.20^{b ; 1}$ & $1.51 \pm 0.21^{b ; 1}$ \\
\hline
\end{tabular}

$a, b, c$ indicate signficance $(\alpha=0.05)$ between species within a water level bin (column-wise); $1,2,3$ indicate significance $(\alpha=0.05)$ within a species across water levels (row-wise).

In black ash, the response of sap flux to $D_{z}$ showed a significant reduction at high water levels compared to low and mean water levels (Figure 2, Table 4). Red maple showed a significantly stronger 
positive response of sap flux to $D_{z}$ at lower water levels when compared to mean and high water levels. There was no significant change with water level in the response of sap flux to $D_{z}$ for yellow birch (Table 4). At low and mean water levels, sap flux response to $D_{z}$ was significantly greater in black ash than in yellow birch, but not greater than red maple. No difference among species was observed in response to $D_{z}$ at high water levels (Table 4).

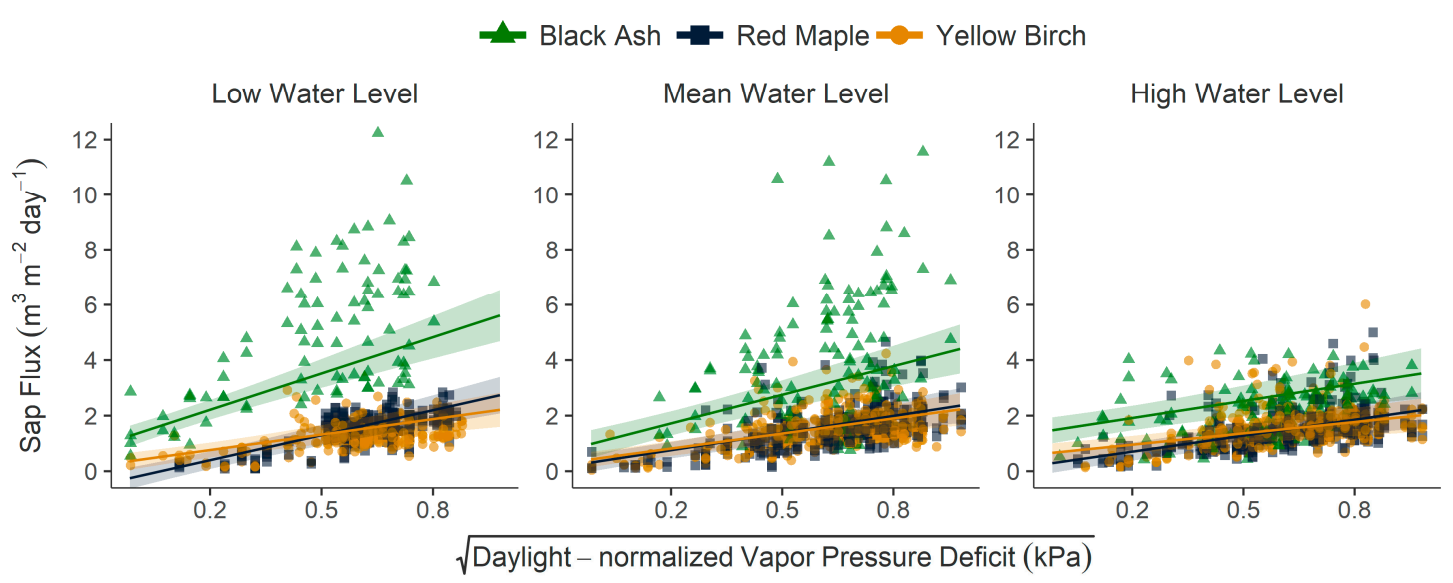

Figure 2. Observed (points) and modeled (lines) daily mean sap flux $\left(\mathrm{m}^{3} \mathrm{~m}^{-2}\right.$ day $\left.^{-1}\right)$ by square-root transformed daylight-normalized vapor-pressure deficit $(\mathrm{kPa})$ within relative water level bins. Shaded regions show $95 \%$ confidence intervals. Modeled daily mean sap flux and shaded regions represent species response to $D_{z}$ at the mean relative water level for each species and water level bin as fit from a single complete model.

Table 4. Marginal mean slope estimates and standard errors of sap flux $\left(\mathrm{m}^{3} \mathrm{~m}^{-2}\right.$ day $\left.^{-1}\right)$ response to square-root transformed daylight-normalized vapor pressure deficit $(\mathrm{kPa})$.

\begin{tabular}{cccc}
\hline Species & Low Water Level & Mean Water Level & High Water Level \\
\hline Black Ash & $5.23 \pm 0.60^{a ; 1}$ & $4.12 \pm 0.61^{a ; 1}$ & $2.46 \pm 0.57^{a ; 2}$ \\
Red Maple & $3.60 \pm 0.48^{a, b ; 1}$ & $2.47 \pm 0.41^{a, b ; 2}$ & $2.30 \pm 0.40^{a ; 2}$ \\
Yellow Birch & $2.23 \pm 0.42^{b ; 1}$ & $2.17 \pm 0.37^{b ; 1}$ & $1.63 \pm 0.39^{a ; 1}$ \\
\hline
\end{tabular}

$a, b, c$ indicate signficance $(\alpha=0.05)$ between species within a water level bin (column-wise); 1, 2, 3 indicate significance $(\alpha=0.05)$ within a species across water levels (row-wise).

\section{Discussion}

\subsection{Effects of Water Level on Sap Flux Rates and Response to Atmospheric Drivers}

As hypothesized, we observed significantly higher sap flux rates in black ash than in codominants. However, the difference between black ash and non-black ash sap flux rates was greatest at low water levels, and lowest at high water levels, which is contrary to the second component of this hypothesis. This response was likely driven by physiological differences between black ash and non-black ash in response to low water levels or changes in water level.

This study did not examine physiological differences or physiological responses between species in these sites though adaptations have been observed in black ash and red maple (see above). Seedling studies have shown that wetland species are known to adapt in a variety of ways, including stomatal closure, hypertrophied lenticels, aerenchyma tissue formation, adventitious root growth, and reproductive resilience. In addition to species-level adaptations, the growing conditions of an individual stem may also lead to the improved tolerance of inundation. Individuals from wet-site populations, or those exposed to early inundation or continued wet soil conditions, recovered more quickly and fully from inundation treatments [57-59]. This suggests that beyond species selection for canopy replacement, stock source and early growing conditions may need to be considered to best 
match the current ecohydrologic function of black ash. Likely, it is a collection of these species- and individual-level adaptations that leads to black ash dominance on wet sites in the Great Lakes region and elsewhere, as Mistch and Rust [60] suggested for riparian tree growth.

Few studies have directly assessed the role of the water table on sap flux or transpiration. Using a similar study design to our own, McJannet [36] found that broad-leaved paperbark (Melaleuca quinquenervia (Cav.) S. T. Blake), a wetland-adapted species, showed no change in transpiration with inundation. Bald cypress (Taxodium distichum (L.) Rich), another species that exhibits canopy dominance in sites with regular and prolonged inundation, significantly increased sap flux during periods of inundation [61]. The results from both broad-leaved paperbark and bald cypress are in contrast to the response of black ash in this study, where a reduction in water levels caused a significant increase in sap flux rates, while inundation led to suppressed sap flux. Further research on black ash in sites less prone to inundation would help determine if the observed high sap flux rates at low water levels are the persistent state for black ash or if these rates occur only as an adaption for recovery from periods of inundation. Broad-leaved paperbark is native to eastern Australia and Oceania [8] and cannot be considered as a replacement species for black ash. The native range of bald cypress extends north to southern Illinois, USA [62], but individual cold hardiness varies, and planted individuals can survive as far north as Hayward, WI, USA [63]. No research has been conducted on bald cypress as a canopy replacement species for black ash.

We did not observe a suppressed response to atmospheric drivers in codominants relative to black ash as water levels increased, as we hypothesized. At all water levels, black ash and red maple responded similarly to $D_{z}$, and at low and mean water levels, black ash showed a significantly stronger response than yellow birch. While black ash and red maple both showed a significantly stronger positive response to $D_{z}$ with decreasing water levels, the response in red maple did not lead to significantly higher sap flux rates. This suggests that red maple is adapted to respond to changing water levels, but the response is less vigorous than that of black ash.

Atmospheric conditions and energy availability are well-known drivers of sap flux $[43,46,64,65]$. In contrast, the results of studies on the effect of soil moisture have been more mixed, with much of the existing research focused on soil moisture deficit as a limiting factor of transpiration [43,66-68]. Specifically, within a wetland-upland transition in northern Wisconsin, Traver et al. [69] report that atmospheric drivers were more important than edaphic conditions for understanding spatial patterns of transpiration. However, significant changes in water table position, such as those observed in these systems following the removal or death of black ash [14,15], can be expected to have a greater impact than the scale of soil moisture variation often studied, as inundation can lead to the suppression of transpiration and growth, even in wetland-adapted species $[27,35,70]$.

A study of black ash in Minnesota found that across sites with varying soil moisture regimes, mean sap flux and response to $D_{z}$ were greater in sites with greater soil moisture [71]. The authors identified differences in sapwood depth and area in the black ash populations among sites, suggesting that individual adaptation or site-induced selection may play a role in the results. The design of our study, and the mixed-modeling approach in our analysis, allow us to test the effect of water level within populations of individuals rather than among populations. It is difficult to compare within-population trends to among-population trends when previous work has shown that adaptation to wet sites and inundation occurs at the species and individual levels (see above), so that systemic variations may occur at different levels.

\subsection{Persistence of Hydrologic Change}

The loss of black ash has been shown to lead to reduced water level drawdown during the growing season and an earlier water level rebound in the fall following senescence [15]. As a result of the inverse relationship between ash sap flux and water level, the rate of drawdown will be further reduced late in the growing season when water levels have receded from their spring peaks. The lack of an increase in sap flux in response to reduced water levels in non-ash species will result in the sustained 
reduction of water level drawdown, leading to earlier water level rebound in the fall. The end result will be persistently higher water levels, both intra- and inter-annually, even if a similarly stocked forest canopy of codominants becomes established. However, differences in microsite survivorship suggest that a less dense forest canopy may be expected.

Black ash consistently occupies the hollows in a hummock and hollow landscape, evidenced by black ash's significantly lower relative root collar elevations. The data presented here cannot confirm that non-black ash prefer hummocks in these sites, but observed water levels were never above non-black ash root collars. The prevalence of black ash in the hollows, paired with a significant increase in the survivorship of non-black ash seedlings planted on hummocks [18], suggest that low-lying microhabitats in these sites may not be suitable for the future growth of mature individuals of these species, precluding a significant area from potential restocking efforts. Following infestation, increased water levels will reduce the prevalence of higher elevation microsites available for seedling establishment, further increasing the potential for a less dense canopy.

Changes in the forest canopy will likely influence site hydrology in ways not examined in this study. Changes in forest canopy closure or composition can be expected to change precipitation and energy inputs to the site. As part of the ongoing research efforts to understand black ash stands and anticipated changes brought on by EAB, the impacts of simulated EAB infestation on throughfall [12] and changes in radiative energy reaching the shrub layer and vegetative ground cover have been examined. Davis et al [12] found that the loss of the ash canopy without a mature canopy replacement increased forest throughfall, though these results were confounded by high canopy heterogeneity. The effect of changes to throughfall may be masked by other inputs, as sourcewater analysis of these wetlands found groundwater contributions throughout the growing season [15]. A reduction of radiative energy reaching the forest floor following EAB-induced mortality relative to the complete removal of black ash will have the effect of suppressing the understory growth response and reducing the potential evaporative demand from the soil surface and pooled water. In this way, a non-black ash canopy with lower relative transpiration could have an even stronger negative effect on growth and evapotranspiration, further contributing to the persistence of hydrologic changes in black ash wetlands if seasonal canopy water use is less than black ash.

\section{Conclusions}

The loss of black ash as the dominant canopy species in wetlands in the northern Great Lakes region will have short-term and potentially longer-term hydrologic impacts. If these sites are retained as forested wetlands, either through natural regeneration or planting, the largest factor affecting the persistence of hydrologic change will be the composition and density of the replacement canopy. Some adaptation or suite of adaptations have resulted in black ash remaining historically dominant at these sites. One expression of these adaptations is an increase in sap flux with receding water levels, so that forest canopy transpiration would be reduced most at times of low water levels following the loss of ash. Reduction of forest canopy water use throughout the growing season would lead to persistently higher water levels during the growing season and a greater fall water level rebound. Increased water levels may lead to a reduction of the elevated microsites favored by current codominants, resulting in a less dense forest canopy, further reducing transpiration. A less dense forest canopy will also lead to reduced canopy interception, while still preventing additional radiative energy from reaching the forest floor and driving surface water evaporation and transpiration in the understory. These effects in combination may result in a permanent alteration of the hydrologic regime in these wetlands toward wetter conditions. Current research has focused on the survival and growth of seedlings of potential replacement species. Our research indicates that the ecohydrologic role of mature individuals may vary significantly between black ash and replacement species, regardless of seedling survival and growth. The ecohydrologic role of mature individuals should be considered when selecting a replacement to ameliorate persistent hydrologic changes. Further study of mature 
individuals of potential replacement species in high water table conditions is needed to inform these decisions.

Supplementary Materials: All data and code used in this analysis is available through the Knowledge Network for Biocomplexity repository [72]. The following are available online at www.mdpi.com/1999-4907/9/3/147/s1, Table S1: Effect size, reported as Cohen's d and exact Tukey-adjusted $p$-value (in parentheses) of pairwise comparisons among species within water level bins and among water level bins within species of estimated marginal means and slopes. Figure S1: Daily mean sap flux of individual probes by (A) daylight-normalized vapor-pressure deficit $\left(D_{z}\right)$ and (B) mean daily water level. Linear models with $95 \%$ prediction intervals fit individually for each driver.

Acknowledgments: Funding was provided through the Great Lakes Restoration Initiative through the USDA Forest Service Northern Research Station (EPA Great Lakes Initiative Template \#664: Future of Black Ash Wetlands in the Great Lakes Region). Additional funds came from the Michigan Technological University School of Forest Resources and Environmental Science, Ecosystem Science Center and the Center for Water and Society at Michigan Technological University. The USFS Ottawa National Forest provided important information regarding potential field site locations. We would like to thank Jon Bontrager, Leah Harrison, Daniel Hutchinson, Erica Jones, Jarrod Nelson, and Nicholas Schriener for their contributions to collecting these data.

Author Contributions: J.S., M.V.G., J.D., T.P., and R.K conceived and designed the experiments; J.S., M.V.G., J.D., and N.B. performed the experiments; J.S., M.V.G., and J.D. analyzed the data; J.S. wrote the paper with contributions from M.V.G., J.D., N.B., N.J.N., T.P., and R.K.

Conflicts of Interest: The authors declare no conflicts of interest.

\section{References}

1. Haack, R.; Jendek, E.; Liu, H.; Marchant, K. The emerald ash borer: A new exotic pest in North America. Newsl. Mich. Entomol. Soc. 2002, 47, 1-5. [CrossRef]

2. Herms, D.A.; McCullough, D.G. Emerald Ash Borer Invasion of North America: History, Biology, Ecology, Impacts, and Management. Annu. Rev. Entomol. 2014, 59, 13-30. [CrossRef] [PubMed]

3. Pugh, S.A.; Liebhold, A.M.; Morin, R.S. Changes in ash tree demography associated with emerald ash borer invasion, indicated by regional forest inventory data from the Great Lakes States. Can. J. For. Res. 2011, 41, 2165-2175. [CrossRef]

4. Aukema, J.E.; Leung, B.; Kovacs, K.; Chivers, C.; Britton, K.O.; Englin, J.; Frankel, S.J.; Haight, R.G.; Holmes, T.P.; Liebhold, A.M.; et al. Economic impacts of Non-Native forest insects in the continental United States. PLOS ONE 2011, 6, e24587. [CrossRef] [PubMed]

5. Willow, A.J. Indigenizing Invasive Species Management: Native North Americans and the Emerald Ash Borer (EAB) Beetle. Cult. Agric. Food Environ. 2011, 33, 70-82. [CrossRef]

6. Gandhi, K.J.K.; Herms, D.A. Direct and indirect effects of alien insect herbivores on ecological processes and interactions in forests of eastern North America. Biol. Invasions 2010, 12, 389-405. [CrossRef]

7. Prasad, A.M.; Iverson, L.R. Little's Range and FIA Importance Value Database for 135 Eastern US Tree Species; Northeastern Research Station, USDA Forest Service: Delaware, OH, USA, 2003; Available online: http: / /www.fs.fed.us/ne/delaware/4153/global/littlefia/index.html (accessed on 22 April 2016).

8. Burns, R.M.; Honkala, B.H. Silvics of North America; Agriculture Handbook 654; Volume 2: Hardwoods; United States Department of Agriculture (USDA), Forest Service: Washington, DC, USA, 1990.

9. Kost, M.A.; Albert, D.A.; Cohen, J.G.; Slaughter, B.S.; Schillo, R.K.; Weber, C.R.; Chapman, K.A. Natural Communities of Michigan: Classification and Description; Michigan Natural Features Inventory: Lansing, MI, USA, 2007.

10. Epstein, E.; Judziewicz, E.; Spencer, E. Wisconsin Natural Heritage Inventory (NHI) Recognized Natural Communities-Working Document; Wisconsin Natural Heritage Inventory: Madison, WI, USA, 2002.

11. Minnesota Department of Natural Resources. Field Guide to the Native Plant Communities of Minnesota: The Prairie Parkland and Tallgrass Aspen Parklands Provinces; Ecological Land Classification Program, Minnesota County Biological Survey, Natural Heritage, Nongame Research Program: St. Paul, MN, USA, 2005.

12. Davis, J.C.; Shannon, J.P.; Bolton, N.W.; Kolka, R.K.; Pypker, T.G. Vegetation responses to simulated emerald ash borer infestation in Fraxinus-nigra dominated wetlands of Upper Michigan, USA. Can. J. For. Res. 2017, 47, 319-330. [CrossRef] 
13. Looney, C.E.; D'Amato, A.W.; Palik, B.J.; Slesak, R.A.; Slater, M.A. The response of Fraxinus nigra forest ground-layer vegetation to emulated emerald ash borer mortality and management strategies in northern Minnesota, USA. For. Ecol. Manag. 2017, 389, 352-363. [CrossRef]

14. Slesak, R.A.; Lenhart, C.F.; Brooks, K.N.; D'Amato, A.W.; Palik, B.J. Water table response to harvesting and simulated emerald ash borer mortality in black ash wetlands in Minnesota, USA. Can. J. For. Res. 2014, 44, 961-968. [CrossRef]

15. Van Grinsven, M.J.; Shannon, J.P.; Davis, J.C.; Bolton, N.W.; Wagenbrenner, J.W.; Kolka, R.K.; Pypker, T.G. Source water contributions and hydrologic responses to simulated emerald ash borer infestations in depressional black ash wetlands. Ecohydrology 2017, 10, e1862. [CrossRef]

16. Looney, C.E.; D'Amato, A.W.; Palik, B.J.; Slesak, R.A. Overstory treatment and planting season affect survival of replacement tree species in emerald ash borer threatened Fraxinus nigra forests in Minnesota, USA. Can. J. For. Res. 2015, 45, 1728-1738. [CrossRef]

17. Looney, C.E.; Amato, A.W.D.; Palik, B.J.; Slesak, R.A. Canopy treatment influences growth of replacement tree species in Fraxinus nigra forests threatened by the emerald ash borer in Minnesota, USA. Can. J. For. Res. 2017, 192, 183-192. [CrossRef]

18. Bolton, N.; Shannon, J.; Davis, J.; Van Grinsven, M.; Noh, N.J.; Schooler, S.; Kolka, R.; Pypker, T.; Wagenbrenner, J. Controls on alternative species seedlings survival and growth in black ash ecosystems threatened by emerald ash borer. Forests 2018. in review.

19. Noh, N.J.; Shannon, J.P.; Bolton, N.W.; Davis, J.C.; Van Grinsven, M.J.; Pypker, T.G.; Kolka, R.K.; Wagenbrenner, J.W. Carbon dioxide fluxes from coarse dead wood in a black ash wetland. Forests 2018, in review.

20. Van Grinsven, M.; Shannon, J.; Bolton, N.; Davis, J.; Wagenbrenner, J.; Kolka, R.; Pypker, T. Gaseous soil-carbon flux responses to simulated emerald ash borer infestations in depressional black ash wetlands. Forests 2018. in review.

21. Brinson, M.M. A Hydrogeomorphic Classification for Wetlands; Wetlands Research Program Technical Report WRP-DE-4; East Carolina University: Greenville, NC, USA, 1993. [CrossRef]

22. Sanford, W.E.; Selnick, D.L. Estimation of Evapotranspiration Across the Conterminous United States Using a Regression With Climate and Land-Cover Data. JAWRA J. Am. Water Resour. Assoc. 2013, 49, 217-230. [CrossRef]

23. Oren, R.; Phillips, N.; Ewers, B.E.; Pataki, D.E.; Megonigal, J.P. Sap-flux-scaled transpiration responses to light, vapor pressure deficit, and leaf area reduction in a flooded Taxodium distichum forest. Tree Physiol. 1999, 19, 337-347. [CrossRef] [PubMed]

24. Sun, G.; McNulty, S.G.; Shepard, J.P.; Amatya, D.M.; Riekerk, H.; Comerford, N.B.; Skaggs, W.; Swift, L. Effects of timber management on the hydrology of wetland forests in the southern United States. For. Ecol. Manag. 2001, 143, 227-236. [CrossRef]

25. Sebestyen, S.D.; Verry, E.S.; Brooks, K.N. Hydrological responses to changes in forest cover on uplands and peatlands. In Peatland biogeochemistry and watershed hydrology at the Marcell Experimental Forest; Kolka, R.K., Sebestyen, S.D., Verry, E.S., Brooks, K.N., Eds.; CRC Press: Boca Raton, FL, USA, 2011; pp. 401-432.

26. EDDMapS Early Detection \& Distribution Mapping System; The University of Georgia-Center for Invasive Species and Ecosystem Health: Athens, GA, USA, 2017.

27. Kozlowski, T.T.; Pallardy, S.G. Acclimation and Adaptive Responses of Woody Plants to Environmental Stresses Acclimation and Adaptive Responses of Woody Plants to Environmental Stresses. Bot. Rev. 2014, 68, 270-334. [CrossRef]

28. Tardif, J.; Dery, S.; Bergeron, Y. Sexual Regeneration of Black Ash (Fraxinus nigra Marsh.) in a Boreal Floodplain. Am. Midl. Nat. 1994, 132, 124-135. [CrossRef]

29. Kozlowski, T.T.; Pallardy, S.G. Stomatal Responses of Fraxinus pennsylvanica Seedlings during and after Flooding. Physiol. Plant. 1979, 46, 155-158. [CrossRef]

30. Gomes, A.R.S.; Kozlowski, T.T. Growth responses and adaptations of Fraxinus pennsylvanica seedlings to flooding. Plant Physiol. 1980, 66, 267-271. [CrossRef] [PubMed]

31. Will, R.E.; Seiler, J.R.; Feret, P.P.; Aust, W.M. Effects of Rhizosphere Inundation on the Growth and Physiology of Wet and Dry-Site Acer-Rubrum (Red Maple) Populations. Am. Midl. Nat. 1995, 134, 127-139. [CrossRef]

32. Pezeshki, S.R.; Chambers, J.L. Stomatal and photosynthetic response of sweet gum (Liquidambar styraciflua) to flooding. Can. J. For. Res. 1985, 15, 371-375. [CrossRef] 
33. Reece, C.F.; Riha, S.J. Role of root systems of eastern larch and white spruce in response to flooding. Plant Cell Environ. 1991, 14, 229-234. [CrossRef]

34. Angeles, G.; Evert, R.F.; Kozlowski, T.T. Development of lenticels and adventitious roots in flooded Ulmus americana seedlings. Can. J. For. Res. 1986, 16, 585-590. [CrossRef]

35. Angelov, M.N.; Sung, S.-J.J.S.; Doong, R.L.; Harms, W.R.; Kormanik, P.P.; Black, C.C.; Black, C.C., Jr. Longand short-term flooding effects on survival and sink-source relationships of swamp-adapted tree species. Tree Physiol. 1996, 16, 477-484. [CrossRef] [PubMed]

36. McJannet, D. Water table and transpiration dynamics in a seasonally inundated Melaleuca quinquenervia forest, north Queensland, Australia. Hydrol. Process. 2008, 22, 3079-3090. [CrossRef]

37. Arguze, A.; Durre, I.; Applequist, S.; Squires, M.; Vose, R.; Yin, X.; Bilotta, R. NOAA's 1981-2010 U.S. Climate Normals: An Overview. Bull. Am. Meteorol. Soc. 2012, 93, 1687-1697.

38. Granier, A. Une nouvelle methode pour la mesure du flux de seve brute dans le tronc des arbres. Ann. Sci. Forestieres (Fr.) 1985, 42, 193-200. [CrossRef]

39. Granier, A. Evaluation of transpiration in a Douglas-fir stand by means of sap flow measurements. Tree Physiol. 1987, 3, 309-320. [CrossRef] [PubMed]

40. Moore, G.W.; Bond, B.J.; Jones, J.A.; Meinzer, F.C. Thermal-dissipation sap flow sensors may not yield consistent sap-flux estimates over multiple years. Trees 2009, 24, 165-174. [CrossRef]

41. Lu, P.; Urban, L.; Zhao, P. Granier's thermal dissipation probe (TDP) method for measuring sap flow in trees: Theory and practice. Acta Bot. Sin. 2004, 46, 631-646.

42. Tang, J.; Bolstad, P.V.; Ewers, B.E.; Desai, A.R.; Davis, K.J.; Carey, E.V. Sap flux-upscaled canopy transpiration, stomatal conductance, and water use efficiency in an old growth forest in the Great Lakes region of the United States. J. Geophys. Res. Biogeosci. 2006, 111, 1-12. [CrossRef]

43. Bovard, B.D.; Curtis, P.S.; Vogel, C.S.; Schmid, H.P. Environmental controls on sap flow in a northern hardwood forest. Tree Physiol. 2005, 25, 31-38. [CrossRef] [PubMed]

44. Western Regional Climate Center. RAWS USA Climate Archive; Desert Research Institute: Reno, NV, USA, 2013.

45. Horel, J.; Splitt, M.; Dunn, L.; Pechmann, J.; White, B.; Ciliberti, C.; Lazarus, S.; Slmmer, J.; Zaff, D.; Burks, J. Mesowest: Cooperative Mesonets in the Western United States. Bull. Am. Meteorol. Soc. 2002, 83, 211-225. [CrossRef]

46. Oren, R.; Zimmermann, R.; Terbough, J. Transpiration in upper Amazonia floodplain and upland forests in response to drought-breaking rains. Ecology 1996, 77, 968-973. [CrossRef]

47. Phillips, N.; Oren, R. Intra- and Inter-Annual Variations in Transpiration of a Pine Forest. Ecol. Appl. 2001, 11, 385-396. [CrossRef]

48. Herbst, M.; Rosier, P.T.W.; Roberts, J.M.; Taylor, M.E.; Gowing, D.J. Edge effects and forest water use: A field study in a mixed deciduous woodland. For. Ecol. Manag. 2007, 176-186. [CrossRef]

49. $\mathrm{Lu}, \mathrm{P}$. A direct method for estimating the average sap flux density using a modified Granier measuring system. Aust. J. Plant Physiol. 1997, 24, 701-705. [CrossRef]

50. Clearwater, M.J.; Meinzer, F.C.; Andrade, J.L.; Goldstein, G.; Holbrook, N.M. Potential errors in measurement of nonuniform sap flow using heat dissipation probes. Tree Physiol. 1999, 681-688. [CrossRef]

51. Lechowicz, M.J. Why Do Temperate Deciduous Trees Leaf Out at Different Times? Adaptation and Ecology of Forest Communities. Am. Nat. 1984, 124, 821-842. [CrossRef]

52. Bates, D.; Mächler, M.; Bolker, B.; Walker, S. Fitting Linear Mixed-Effects Models Using lme4. J. Stat. Softw. 2015, 67, 1-48. [CrossRef]

53. R Core Team. R: A Language and Environment for Statistical Computing, Version 3.4.3; R Foundation for Statistical Computing: Vienna, Austria, 2017.

54. RStudio Team. RStudio: Integrated Development Environment for R; RStudio, Inc.: Boston, MA, USA, 2012.

55. Lenth, R.V. emmeans: Estimated Marginal Means, Aka Least-Squares Means. R Package Version 1.1.2. 2018. Available online: https:/ /CRAN.R-project.org/package=emmeans (accessed on 22 April 2017).

56. Kamil, B. MuMIn: Multi-Model Inference. R Package Version 1.40.4 2018. Available online: https:/ /CRAN. R-project.org / package=MuMIn (accessed on 22 April 2017).

57. Anella, L.B.; Whitlow, T.H. Photosynthetic Response to Flooding of Acer rubrum Seedlings from Wet and Dry Sites. Am. Midl. Nat. 2000, 143, 330-341. [CrossRef] 
58. Yan, X.L.; Xi, B.Y.; Jia, L.M.; Li, G.D. Response of sap flow to flooding in plantations of irrigated and non-irrigated triploid poplar. J. For. Res. 2015, 20, 375-385. [CrossRef]

59. Wang, S.; Callaway, R.M.; Zhou, D.W.; Weiner, J. Experience of inundation or drought alters the responses of plants to subsequent water conditions. J. Ecol. 2017, 105, 176-187. [CrossRef]

60. Mitsch, W.J.; Rust, W.G. Tree Growth Responses to Flooding in a Bottomland in Northeastern Illinois. For. Sci. 1984, 30, 499-510.

61. Duberstein, J.A.; Krauss, K.W.; Conner, W.H.; Bridges, W.C.; Shelburne, V.B. Do hummocks provide a physiological advantage to even the most flood tolerant of tidal freshwater trees? Wetlands 2013, 33, 399-408. [CrossRef]

62. Burns, R.M.; Honkala, B.H. (Eds.) Silvics of North America; Agriculture Handbook 654; Volume 1: Conifers; United States Department of Agriculture (USDA), Forest Service: Washington, DC, USA, 1990.

63. Heim, M. Personal communication, 2017.

64. Ewers, B.E.; Mackay, D.S.; Gower, S.T.; Ahl, D.E.; Burrows, S.N.; Samanta, S.S. Tree species effects on stand transpiration in northern Wisconsin. Water Resour. Res. 2002, 38, 1-11. [CrossRef]

65. Adelman, J.D.; Ewers, B.E.; MacKay, D.S. Use of temporal patterns in vapor pressure deficit to explain spatial autocorrelation dynamics in tree transpiration. Tree Physiol. 2008, 28, 647-658. [CrossRef] [PubMed]

66. Oren, R.; Pataki, D.E. Transpiration in response to variation in microclimate and soil moisture in southeastern deciduous forests. Oecologia 2001, 127, 549-559. [CrossRef] [PubMed]

67. Ford, C.R.; Goranson, C.E.; Mitchell, R.J.; Will, R.E.; Teskey, R.O. Modeling canopy transpiration using time series analysis: A case study illustrating the effect of soil moisture deficit on Pinus taeda. Agric. For. Meteorol. 2005, 130, 163-175. [CrossRef]

68. McLaren, J.D.; Arain, M.A.; Khomik, M.; Peichl, M.; Brodeur, J. Water flux components and soil water-atmospheric controls in a temperate pine forest growing in a well-drained sandy soil. J. Geophys. Res. Biogeosci. 2008, 113. [CrossRef]

69. Traver, E.; Ewers, B.E.; Mackay, D.S.; Loranty, M.M. Tree transpiration varies spatially in response to atmospheric but not edaphic conditions. Funct. Ecol. 2010, 24, 273-282. [CrossRef]

70. Pezeshki, S.R.; Anderson, P.H. Responses of three bottomland species with different flood tolerance capabilities to various flooding regimes. Wetl. Ecol. Manag. 1996, 4, 245-256. [CrossRef]

71. Telander, A.C.; Slesak, R.A.; D'Amato, A.W.; Palik, B.J.; Brooks, K.N.; Lenhart, C.F. Sap flow of black ash in wetland forests of northern Minnesota, USA: Hydrologic implications of tree mortality due to emerald ash borer. Agric. For. Meteorol. 2015, 206, 4-11. [CrossRef]

72. Shannon, J.; Van Grinsven, M. Sap Flux and Water Levels for Black Ash Wetlands in western Michigan, USA from 2012 to 2014. Knowl. Netw. Biocomplex. 2018. [CrossRef] 